Discussion Paper No. 10-076

\title{
Pension Funds' Performance in Strongly Regulated Industries in Central Europe: Evidence from Poland and Hungary
}

Martin Bohl, Judith Lischewski, and Svitlana Voronkova

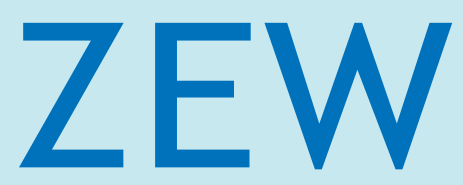

Zentrum für Europäische Wirtschaftsforschung $\mathrm{GmbH}$

Centre for European

Economic Research 
Discussion Paper No. 10-076

\title{
Pension Funds' Performance in Strongly Regulated Industries in Central Europe: Evidence from Poland and Hungary
}

\author{
Martin Bohl, Judith Lischewski, \\ and Svitlana Voronkova
}

Download this ZEW Discussion Paper from our ftp server:

ftp://ftp.zew.de/pub/zew-docs/dp/dp10076.pdf

Die Discussion Papers dienen einer möglichst schnellen Verbreitung von neueren Forschungsarbeiten des ZEW. Die Beiträge liegen in alleiniger Verantwortung der Autoren und stellen nicht notwendigerweise die Meinung des ZEW dar.

Discussion Papers are intended to make results of ZEW research promptly available to other economists in order to encourage discussion and suggestions for revisions. The authors are solely responsible for the contents which do not necessarily represent the opinion of the ZEW. 


\section{Non-Technical Summary}

Following the proposal of the World Bank in the end of the 1990s, a number of Central European countries have extended their pay-as-you-go pension systems by a capital-market-based element in the form of privately managed pension funds. As a result of these reforms, new type of financial institutions - defined contribution pension funds - have been introduced in these countries. To guarantee the security of future pensions, governments imposed regulation on the investment practices and performance of the pension funds. This approach to regulation differs from the traditional "prudent man" rules applied in a number of developed countries. This paper presents an analysis of pension funds' performance in Poland and Hungary, two Central European countries characterized by strong regulation of their private pension fund industries. The paper extends the literature which has so far mostly focused on performance of pension fund industries facing no or only limited regulation. We find that the performance of pension funds in the two studied countries differs. While we do not find convincing evidence of outperformance by Polish pension funds, we find strong evidence of underperformance by Hungarian pension funds. The results are robust to time-variation. The paper considers possible explanations behind these findings. The results of the paper should be of interest for policy-makers seeking to achieve optimal performance of the pension systems and academics in the research area of pension funds.

\section{Das Wichtigste in Kürze}

Gemäß des Vorschlags der Weltbank Ende der 1990er-Jahre erweiterten mehrere zentraleuropäische Länder ihre bisherigen nach dem Umlageverfahren konzipierten staatlichen Rentensysteme um ein kapitalmarktbasiertes Element in Form von privaten Pensionsfonds. Aufgrund dieser Reformen entstand mit der Einführung von beitragsorientierten Pensionskassen eine neue Form von Finanzinstituten. Um zukünftige Pensionszahlungen sicherzustellen, wurden Regulierungsmaßnahmen für die Investitionspraxis und Performance der Pensionsfonds eingerichtet. Diese regulatorischen Rahmenbedingungen unterscheiden sich von den traditionellen "Prudent-Man"-Richtlinien, die in Märkten der meisten Industriestaaten angewendet werden. Die vorliegende Arbeit umfasst eine Analyse der Performance von Pensionsfonds in Polen und Ungarn, zwei zentraleuropäischen Ländern deren private Pensionsfonds stark reguliert sind. Diese Arbeit erweitert die einschlägige Literatur, die sich bis dato auf die Performance von Pensionsfonds in wenig oder gar nicht regulierten Märkten konzentriert. Es wird gezeigt, dass sich die Performance der Pensionsfonds in den zwei untersuchten Ländern unterscheidet. Wir finden Hinweise, wenn auch keine eindeutigen Beweise, für eine Outperformance der polnischen Pensionsfonds. Die Underperformance ungarischer Pensionsfonds können wir hingegen deutlich nachweisen. Die Ergebnisse sind robust gegen Veränderungen der Stichprobe über die Zeit. Die Studie liefert zudem mögliche Erklärungen für diese Ergebnisse. Die Erkenntnisse der Arbeit dürften für Politiker, die auf eine optimale Performance der heimischen Alterssicherungssysteme abzielen, sowie für Wissenschaftler im Bereich der Pensionsfonds von Interesse sein. 


\title{
Pension Funds' Performance in Strongly Regulated Industries in Central Europe: Evidence from Poland and Hungary ${ }^{1}$
}

\author{
Martin Bohl $^{a *}$, Judith Lischewski ${ }^{a * *}$ and Svitlana Voronkova ${ }^{b * * *}$ \\ ${ }^{a}$ Department of Economics, Westfälische Wilhelms-University Münster, Germany \\ ${ }^{b}$ Centre for European Economic Research (ZEW), Mannheim, Germany
}

September 2010

\begin{abstract}
This paper presents an analysis of pension funds' performance in Poland and Hungary, two Central European countries characterized by strong regulation of their private pension fund industries. Thus, the paper extends the literature which has so far mostly focused on performance of pension fund industries facing no or limited regulation. We find that the performance of pension funds in the two studied countries differs. While we do not find convincing evidence of outperformance by Polish pension funds, we find strong evidence of underperformance by Hungarian pension funds. The results are robust to time-variation. The paper considers possible explanations behind these findings. The results of the paper should be of interest for policy-makers seeking to achieve optimal performance of the pension systems and academics in the research area of pension funds.
\end{abstract}

\section{JEL-Code: G23, G28}

Keywords: Pension fund management, investment and performance regulation, performance measurement, Central European stock markets, Emerging Markets.

* Corresponding Author: Martin Bohl, Department of Economics, Westfälische Wilhelms-University Münster, Am Stadtgraben 9, D-48143 Münster, Germany, phone: +49 251 83-25005, martin.bohl@wiwi.uni-muenster.de

** Judith Lischewski, Department of Economics, Am Stadtgraben 9, Westfälische Wilhelms-University Münster, D-48143 Münster, Germany, phone: +49 251 83-28200, judith.lischewski@wiwi.uni-muenster.de

*** Svitlana Voronkova, Centre for European Economic Research (ZEW), L7,1 68161 Mannheim, Germany, phone: +49 621 1235-379, voronkova@zew.de

\footnotetext{
${ }^{1}$ The authors would like to thank Analizy Online (www.analizy.pl) for providing necessary data. Parts of this paper were written while Martin T. Bohl was visiting the International Institute of Integration Studies in Dublin and while Svitlana Voronkova was employed at the Trinity College Dublin. Martin T. Bohl is also grateful to the Alexander von Humboldt Foundation for financial support. We are indebted to participants of the international conference "Economics of Central and Eastern Europe: Convergence, Opportunities and Challenges", the CESifo Workshop on "Re-thinking Privatization of Social Security", the 6th INFINITI Conference on International Finance, the International Conference "Monetary and financial transformations in CEECs", the XVII International Tor Vergata Conference on Banking and Finance "Emerging Markets,
} 


\section{Introduction}

Following the proposal of the World Bank (1994), in the end of the 1990s pay-as-you-go pension systems in Central European (CE) countries have been complemented by a capitalmarket-based element in the form of privately managed pension funds. The pension reform aimed to facilitate accumulation of future pensions and reduce the fiscal burden resulting from excessive pension liabilities.

Since investment in private pension funds in these countries is mandatory, investment limits and performance regulations on pension funds' activities were imposed to avoid losses of contributed money and guarantee future pension payments. In addition, regulation was expected to facilitate trust and acceptance of the new pension system, as well as to contribute to the development of capital markets of the respective countries. The presence of such strict investment regulations constitutes a peculiar feature of the environment, in which Central European pension funds operate, distinguishing it from the environment of many developed financial markets where often only the so-called "prudent man" rule applies. Poland and Hungary - two diverse Central European countries in terms of their economic conditions and their degree and manner of regulatory framework - are chosen to provide a basis for the present study.

Up to our knowledge, the literature discussing pension fund performance in Central and Eastern European countries within an asset pricing framework is scarce. Stanko (2003) represents a notable exception in this respect. Stanko (2003) studies 21 Polish pension funds from June 1999 to March 2003. In addition to Sharpe and Treynor ratios, he uses several unconditional asset pricing models to estimate funds' alphas. Stanko (2003) finds that compared to the international results, the Polish pension industry recorded high economically and statistically significant abnormal returns. He believes this result is to some extent due to managers' superior information over individual investors and their timing ability, as well as due to factors beyond the power of the fund managers, such as bullish market and market inefficiency. Another paper studying pension funds in Poland is written by Zalewska (2006). However, Zalewska is concerned with the issue of the effects of enforced home bias on the development of the Polish stock market, rather than with the performance of pension funds.

\footnotetext{
Currencies and Stability", the seminar of the European Network on Research on Pensions (ENRSP), and the research seminar of the Westfälische Wilhelms-University, especially to Laurence Kotlikoff, Gary Burtless, Stephen Zeldes, Roland Eisen, Tetyana Dubovyk, Janusz Brzeszczynski, Bogdan Dima, Gerry Dwyer, Jana Riedel, Gordon Roberts, Christian Salm, Michael Schuppli, David Sondermann, Heinz-Dietrich Steinmeyer, Yves Stevens and Marek Szczepański, for helpful comments and suggestions.
} 
In a study on Hungarian pension funds Impavido and Rocha (2006) address a wider set of issues pertaining to the pension reform, such as effect on capital market development, regulation of the accumulation and payout phases and future reform agenda. Performance of the pension funds within the new second pillar of the Hungarian pension system is therefore only one of the issues addressed in this paper. Impavido and Rocha (2006) discuss net and gross investment returns of the Hungarian pension funds and do not estimate funds' excess returns. The authors find that the average return performance of Hungarian pension funds was rather disappointing. In some years during the period 1998-2004 the average real net rate of return was even negative. Net rate of return in all but one year was lower than wage growth. Also, the accumulated rate of return in Hungary appears to be lower than in Poland and all of Latin American countries who carried out similar reform a decade earlier.

The present paper contributes to the existing literature in the following ways. First, it provides empirical evidence on the performance of pension funds in two Central European countries. Second, it complements the available evidence on performance of pension funds operating in lax regulatory environments and guided by "prudent man" laws by analyzing the performance of pension funds acting under much stricter regulations. Third, as the reformed pension systems in both countries are still at a relatively early stage, their regulatory frameworks might still develop and improve. In this respect we believe that the paper's findings might be of interest for policy makers and pension fund managers in Central European countries. Additionally, the findings of the paper might be relevant for policy makers seeking to implement a similar system in their country.

We use monthly and quarterly data on pension fund portfolio returns, returns on local stock and bond market indices and local Treasury bills. The data allows us to decompose the assets under management into different asset classes. Established performance measures, such as Sharpe ratio, Treynor ratio and Jensen's alpha are used to evaluate funds' performance. To calculate Jensen's alpha, several asset pricing models were estimated: CAPM and Henriksson and Merton (1981) and Treynor and Mazuy (1966) timing models. In order to account for the dynamic development of the emerging markets and the possible resulting time-variation in the beta-coefficients, we extend the models by time-related interaction dummies. All models were estimated using pooled OLS estimator with Driscoll and Kraay (1998) standard errors to correct for spatial cross-sectional and temporal dependence.

Firstly, we find that investment limits and performance regulations influence the invest- 
ment decisions of pension funds. The exact effect depends on the type of the performance evaluation benchmark used. In Poland it leads to similar portfolio compositions of the funds across asset classes, while in Hungary it leads to an excessive investment into government securities. Secondly, we do not find a conclusive evidence of selectivity ability by Polish pension fund managers. Although the estimation results of the basic CAPM show evidence for a selectivity ability of pension fund managers in Poland when a blue-chip market index is used as an equity market benchmark, the results can not be confirmed when a broader market index is used to measure stock market performance. In case of Hungarian pension funds we find a strong evidence of underperformance. Finally, we place our findings in a broader context by comparing our results with those on pension fund performance in selected developed markets. Given the mandatory nature of the defined-contribution pension funds in Poland and Hungary and their substantial portion of future pensions, the performance of pension funds in the countries is one of the key indicators for judging the success of the pension reforms. Analysis of the pension fund portfolio composition and performance allows policy-makers to judge about the expected and realized investment strategies by pension fund managers and use this information for further improvement of pension fund regulation. In these respects the present study provides further evidence on the development of the pension reforms in the Central European countries, which might be of interest for policy makers, fund managers and general public in these countries, as well as for the academics studying pension systems.

\section{Pension Fund Industry and Regulatory Framework in Poland and Hungary}

As pointed out by Chan-Lau (2005), the main determinants of pension funds' investment performance may be grouped into three categories: investment regulations, investment practices and the ability to diversify the portfolios abroad. Below we review those factors in the context of mandatory pension funds acting on the Polish and Hungarian markets.

The first transfer of money to Polish pension funds took place on May 19, 1999. Due to organizational, as well as financial problems, the majority of Polish pension funds started their activity on the market in June 1999. As of October 1999, the number of active funds rose from 15 to 21. Since 2004, due to acquisitions and a merger, it has been reduced to 15 
again. The Polish pension fund market is highly concentrated. In terms of market share, as measured by net assets, the market can be divided into three groups: very large funds (market share higher than 20\%), large funds (market share between 5\% and 20\%) and small funds (market share below 5\%). In August 2007, the funds Commercial Union (27\%) and ING (23\%), representing the group of largest funds, jointly held $50 \%$ of the market share. Approximately a further quarter was held by the group of large funds that included PZU (14\%) and AIG (8\%). The remaining quarter of the market was distributed between 11 small funds with market share below 5\%. In August 2007 Polish pension funds held about 49 billion US-\$ of net assets, amounting to $12 \%$ of the Polish GDP in 2007 (www.knf.gov.pl).

Polish pension funds constitute the second pillar of the reformed pension system. They are defined-contribution funds. This means that the amount of future pensions accumulated in the second pillar depends solely on returns on invested assets. Participation in the second pillar is mandatory for individuals born after 1968 (AP Information Services (2009)). Employees transfer $7.3 \%$ of their gross salary through the Social Insurance Institution (ZUS) on their individual accounts in the pension funds (KNF (2008)). Employees are free to choose a fund in which to invest.

In addition to the prudent man rules, Polish pension fund managers have to follow quantitative investment limits regulated in the Law on Organisation and Operation of Pension Funds from August 28, 1997. Here we focus on quantitative limits imposed on investments in particular types of assets and do not review the regulations restricting the concentration of holding securities of the same issuer. The overall investment in bonds and bills issued by Treasury and National Bank of Poland is not subject to constraints. A maximum of $40 \%$ of the accumulated assets under management may be invested in shares of domestic listed companies, in addition, no more than $25 \%$ in investment funds. The investment in bank deposits and foreign assets is limited to a maximum of $20 \%$ and $5 \%$, respectively. According to Polish law, investments into derivatives may only be permitted by the Council of Ministers in exceptional cases. During the present sample period pension funds were banned from investing in such assets. Investing into real estate is prohibited (OECD (2006)).

Table 1 provides data on the quantitative limits faced by Polish pension funds and their actual portfolio composition for the period between April 2002 and August 2007. We provide the average of all pension funds' portfolio shares. The quantitative regulations are deemed responsible for the distribution of shares versus bonds in the funds' portfolios of about $31 \%$ 
to $64 \%$. The remaining marginal fraction of the portfolios is dispersed across other asset categories. Table 1 reveals that Polish pension funds diversify less than they are allowed by the quantitative investment limits. In particular, the fraction of investment in foreign assets is substantially lower than the legal limit of $5 \%$ (www.knf.gov.pl). Diverse reasons might lead to this outcome. An analysis of the underlying portfolios of individual funds shows, that only the four largest funds invest in foreign assets. Smaller funds might refrain from investing abroad due to high information costs associated with such investments and a lack of experience.

Table 1 about here

To guarantee future pension payments, the pension funds are required to achieve a minimum rate of return on their investments. The Polish law defines this mandatory minimum as "the rate of return lower by $50 \%$ than the weighted average rate of all funds established for a given period, or the rate of return four percentage points lower than the aforesaid average, whichever is lower". The measure is calculated and announced on a quarterly basis for the previous 36-month period. A rate below the required threshold should be made up from pension funds' reserve account ${ }^{1}$. If these assets will not suffice to cover the deficit, it has to be financed by the so-called Guarantee Fund, which was introduced to secure future pension payments $^{2}$ (www.knf.gov.pl). The regulatory framework does not include a definition of a certain investment policy. Thus, pension funds in Poland are free to choose their investment strategy.

Mandatory pension funds in Hungary were introduced in January 1998 as a second tier within the new three-tier pension system (World Bank (2007)). Four funds started their activity on the market during the first quarter of 1998. Since 200118 mandatory private pension funds have been active on the market. By the end of 2007 they managed 11.5 billion US-\$ of assets (at market prices), which accounted for $7.8 \%$ of Hungarian GDP. The funds had 2.8 million members (www.pszaf.hu). The citizens covered by the second pillar include

\footnotetext{
${ }^{1}$ Pension funds shall transfer funds to a reserve account amounting up to $0.005 \%$ of the value of the managed net assets of the fund. If the fund fails to serve the reserve account they are charged a fine by the supervision authority.

${ }^{2}$ Such performance regulations in combination with the high concentration of the pension fund industry in Poland can be seen as reasons for herding behavior by Polish pension funds and for similar composition of the funds' portfolios. Voronkova and Bohl (2005) investigate this typical feature of the Polish pension fund market in detail.
} 
new labor entrants below the age of 42 and those who opted to join the new system. The employees contribute $7 \%$ of their taxable income towards the second pillar pension. As in case of Poland, employees are free to choose in which fund to invest. The concentration of the Hungarian pension fund market is similar to the one in Poland. At the end of 2005 one very large and four large Hungarian pension funds, holding about $80 \%$ of assets, dominated the market, whilst the very large fund held $25 \%$ on its own. The remaining $20 \%$ of the market was held by 13 small funds. The oligopolistic structure of the Polish and Hungarian pension fund markets is similar to the one in the UK, where $50 \%$ of voluntary pension fund assets were held by five managing houses in 2002 (Blake and Timmermann (2002)).

Investment limits in Hungary are somewhat less strict than those in Poland. Holdings in government bonds and bank deposits are not limited. Investment in domestic stocks and investment funds is limited to $50 \%$ each, investment in foreign assets is limited to $30 \%$ and investment in real estate may reach a maximum of $10 \%$. It is prohibited for pension fund managers to invest in loans (OECD (2006)). Despite the less restrictive limits, Hungarian pension fund managers diversify their portfolios even less, which becomes apparent from the data provided in Table 1 . More than $75 \%$ of assets are invested in government bonds, while only $10 \%$ of assets are held in stocks. The large proportion of government bonds in the pension funds' portfolios is likely to be caused by the performance regulation being linked to the performance of Hungarian government bonds. Pension fund managers, striving to meet the performance requirements, avoid investing in equities, which are associated with more risk. As is the case of Polish pension funds, only minor fractions of the overall portfolios are invested in foreign assets.

In order to ensure the security of future pensions the Hungarian Financial Supervisory Authority (HFSA) applies the following regulations to pension funds' performance. Funds are expected to achieve a minimum rate of return, which is defined as $85 \%$ of the return on long-term government bonds. Funds failing to achieve the performance target for three consecutive years may be subject to a government enquiry. However, in contrast to Poland, the Hungarian pension fund managers cannot be held liable for not delivering a minimum rate of return since their assets are not kept segregated from the participants' assets. Unlike in Poland, pension funds in Hungary are subject to long-term performance regulations: the pensions that they disburse should be at least at the level of $25 \%$ of a comparable public pension benefit on the retirement at the statutory pension age. In particular, after 15 
years of participation in a pension fund, the total pension from the first and the second pillar should reach $92 \%$ of a corresponding old-style pension. As it is the case in Poland, restrictions regarding the investment strategies of the pension funds are not part of the regulatory framework.

It should be pointed out that Hungarian pension funds suffer from a relatively small and illiquid stock market. The number of stocks listed on Budapest Stock Exchange fluctuated between 49 and 66 during the sample period. However, the five most traded shares accounted for over $80 \%$ of the stock market capitalization and around $90 \%$ of its turnover (Budapest Stock Exchange (2006)). This, in combination with the present investment and performance regulations, has resulted in a very high fraction of domestic bonds in the Hungarian pension fund portfolios, which amounted to about 70\% during our sample period (HFSA (2005)). Thus the circumstances of the Hungarian stock market, along with the investment regulation, effectively negate the opportunity to invest up to $50 \%$ of the portfolio into equities.

Analysis of the portfolio compositions of the pension funds in the two countries shows that pension fund managers heavily invest in government bonds. Pension funds in both countries pursue conservative investment strategies and their investments in other allowed financial instruments apart from government bonds are minor, particularly so in Hungary ${ }^{3}$.

\section{Performance Measures}

To provide a first insight into the investment performance of the pension funds and their ranking Sharpe (1966) and Treynor (1965) ratios are calculated. While the Sharpe ratio considers the total risk of a portfolio, the Treynor ratio takes the systematic risk into account. A well diversified portfolio features a total risk equal to the systematic risk. Thus, through a comparison of the two ratios, a rough estimate of the diversification capability of the managers is possible. An identical ranking of the performance measures indicates a high diversification capability.

Detailed information about the portfolio structure of the individual funds is available for a limited period only, due to lack of available data. Therefore, the analysis is constrained to established unconditional performance measures based on the CAPM. We expand the

\footnotetext{
${ }^{3}$ The trade-off between investment regulations and benefits from diversification is an important issue discussed in the literature (Antolin et al. (2009)). However, up to our knowledge, it has not yet been addressed in the context of CEE countries.
} 
models by interaction dummies for each year to consider the dynamic development of the emerging stock markets, and the potential resulting time-variation of the beta-coefficients. Using a stepwise reduction of the interaction-dummy coefficients we ensure that only the significant time-effects influence the estimation. The extended Jensen (1968) regression is given by equation (1):

$$
r_{i t}-r_{f t}=\alpha_{i}+\beta_{i}\left(r_{m t}-r_{f t}\right)+\sum_{\varpi} \varphi_{\varpi i} \delta_{\varpi}\left(r_{m t}-r_{f t}\right)+\epsilon_{i t} .
$$

$r_{i t}$ is the return of pension fund $i$ at time $t, r_{f t}$ the risk-free rate and $r_{m t}$ the return of the market portfolio. The coefficient $\alpha_{i}$ indicates Jensen's $\alpha$ of fund $i$, the coefficient $\beta_{i}$ denotes its beta. $\varpi$ is the vector of years for which the dummy variables are included depending on the longest available time-series for fund $i$. $\psi_{\varpi i}$ indicates the coefficient of the time-related interaction dummy. $\delta_{\varpi}$ is a dummy-variable, which takes the value of 1 for year $\varpi$ and 0 otherwise. While a positive and significant $\alpha$ indicates a superior risk-adjusted performance of a fund, a negative value reports an inferior performance assuming that the fund manager potentially does not show stock selection ability, but timing ability (Cesari and Panetta (2002)). Stock selection ability refers to the allocation of funds' assets within different investment instruments, whereas market timing concerns changes of the funds' asset allocation across those instruments.

As was pointed out above, in addition to stocks, pension funds' portfolios in both countries contain a significant fraction of bonds. To account for the presence of bonds in the pension fund portfolios, we construct a capitalization-weighted market index based on equity and government bond indices. The details of the index construction are provided in Section 4.

Jensen's $\alpha$ is affected by the information available to the manager. Exclusive availability of security-specific information leaves the measure unbiased. However, if the management resorts to timing information its value is generally biased downwards (Cesari and Panetta (2002)). In order to capture possible market timing ability of fund managers we apply the approaches by Treynor and Mazuy (1966) and Henriksson and Merton (1981). The TreynorMazuy approach is based on the idea that managers are able to predict the market trend and the extent of future excess returns. Thus, a fund manager adapts the beta of the fund continuously to his forecasted market trend. The fraction of the market portfolio held by the managers increases (decreases) when they expect the general stock market to rise (fall). 
In order to capture the timing ability, Treynor and Mazuy (1966) add the squared excess return of the market portfolio to the basic Jensen regression:

$$
r_{i t}-r_{f t}=\alpha_{i}+\beta_{i}\left(r_{m t}-r_{f t}\right)+\gamma_{i}\left(r_{m t}-r_{f t}\right)^{2}+\sum_{\varpi} \varphi_{\varpi i} \delta_{\varpi}\left(r_{m t}-r_{f t}\right)+\epsilon_{i t} .
$$

$\gamma_{i}=0$ indicates no timing ability, and $\gamma_{i}>0$ that the manager has access to and successfully uses timing information, while $\alpha_{i}$ measures the share of the fund's performance achieved through selectivity. The contribution to the performance of a fund achieved by timing ability corresponds to the product of the $\gamma$ coefficient and the variance of the excess market return $\sigma_{e r m}^{2}$. The sum of the selection contribution and the timing contribution is equal to the total performance. The Treynor-Mazuy approach may only detect timing ability, when the structure of the estimated model complies with the managers' timing ability. Using a multi-beta-strategy or the three-factor model by Fama and French (1993) may solve this shortcoming (Prather and Middleton (2006)).

The Henriksson-Merton approach (1981) is based on the idea that managers use forecasts of excess market return for the following period, and adjust the beta accordingly. The product of the excess market return and a dummy variable is added to the basic Jensen regression:

$$
r_{i t}-r_{f t}=\alpha_{i}+\beta_{i}\left(r_{m t}-r_{f t}\right)+\gamma_{i}\left(r_{m t}-r_{f t}\right) D_{t}+\sum_{\varpi} \varphi_{\varpi i} \delta_{\varpi}\left(r_{m t}-r_{f t}\right)+\epsilon_{i t} .
$$

The dummy variable $D_{t}$ takes the value 0 if $r_{m t}-r_{f t}=0$ and -1 if $r_{m t}-r_{f t} \leq 0$. A positive value of $\gamma_{i}$ indicates that the manager has timing ability. The Henriksson-Merton approach regards time-varying beta-factors of the Jensen model as evidence for timing activity. However, instability of this risk-measure is not necessarily due to timing activities. Another critical assumption of the approach is that managers only take the forecasted trend of the market return into account and not the absolute level of the excess return in order to determine the beta. The performance achieved by timing and selectivity may be biased, if their behavior does not correspond to the assumptions of the model.

Since we are interested in the performance of the whole sector, rather than in the individual performance of the pension funds, we estimate the models using pooled ordinary least squares (OLS). Given the small samples, pooling information across funds has the potential advantage of gaining power compared to estimates based on a fund-by-fund analysis (Chevalier and Ellison (1999)). We correct the standard errors for spatial cross-sectional and 
temporal dependence by using the method proposed by Driscoll and Kraay (1998).

\section{Data}

Our empirical investigation is based on two samples containing panel data of Polish and Hungarian private pension funds. The sample covering portfolio returns of Polish pension funds runs from June 1999, the time the majority of funds entered the market, to August 2007. The data for the 52-week local t-bill yield, which proxies the risk-free-rate in Poland, is available up to April 2007. The estimations are adjusted accordingly where necessary. The 21 Polish pension funds can be classified into survived and discontinued funds. The group of survivors, containing 15 pension funds, includes those funds active on the market during the whole sample period ${ }^{4}$. The group of discontinued funds contains six funds entering the market late and quitting it before the end of the sample period, respectively ${ }^{5}$. The classification of the pension funds allows us to identify the influence of discontinued pension funds on the aggregate results.

The returns of the pension funds, provided by Analizy Online under www.analizy.pl, are measured as the monthly change in pension funds' unit value. The end-of-month data of the Polish total return index WIG and the price index WIG20 are used as proxies for the Polish stock market portfolio. The choice of the benchmark is decisive, as it is difficult to distinguish between benchmark inefficiency and abnormal returns due to the interdependence between performance evaluation and the choice of the benchmark (Lehmann and Modest (1987), Grinblatt and Titman (1994), Blake and Timmermann (2002)). The use of different benchmarks provides a possibility to check the robustness of the estimations. Additionally, we use the WIG20 along with the WIG, since Polish pension fund managers are known to invest heavily in blue chips due the existing investment constraints and performance regulation. Monthly Morgan Stanley Capital International bond index (MSCI) for Poland, a total return index, is used as a benchmark for the returns on bonds held by the funds. The risk-free rate, as well as the benchmark indices, are obtained from Thomson Financial Datastream.

\footnotetext{
${ }^{4}$ Pekao and Allianz, entered the market only in August 1999 and September1999, respectively. As they did not leave the market until August 2008, they are classified into the group of survived pension funds.

${ }^{5}$ Arka, Kredyt Banku, Epoka and Rodzina entered the market late, and quit the market prior to 2005. Pioneer and ego entered the market already in 1999; however, they quit the market already prior to 2003.
} 
The data on returns of Hungarian private pension funds are provided by the Hungarian Financial Supervisory Authority (HFSA). The dataset contains quarterly annualized net rates of returns of 18 mandatory private pension funds from the first quarter of 1998 until the last quarter of 2004. Due to the fact that some pension funds only started their activity on the market after the first quarter of 1998 and due to additional missing values, the set of data is fragmentary. The names of the pension funds are not provided by the HFSA. Instead, pension funds are identified by numbers. As a proxy for the local risk-free-rate, we use the Hungarian one-year t-bill rate. The market portfolio benchmark is proxied by the Budapest stock index (BUX). In order to incorporate a benchmark for the returns on bonds held by the funds, the total return MSCI bond index for Hungary is used. The Hungarian t-bill-rate is obtained from Global Financial Data (www.globalfinancialdata.com). The BUX and the MSCI indices are obtained from Thomson Financial Datastream. For the purpose of the empirical analysis continuously compounded rates of return are used.

We construct a capitalization-weighted market benchmark index which is a combination of the domestic government bond and equity indices. The weights of the bond and equity components were calculated using the monthly (in case of Poland) and quarterly (in case of Hungary) portfolio-level data on holdings of bonds and equities by pension funds.

\section{Empirical Findings and Comparison with Existing Literature}

Sharpe and Treynor ratios for the Polish pension funds are presented in Table 2. As the returns of the pension funds are similar to the level of the t-bill rates, the absolute values of the performance ratios are small. The ratios are mainly positive and have similar rankings. Negative Sharpe and Treynor ratios are due to a negative total return of the corresponding pension fund. Indeed, the ranking of the Treynor and Sharpe ratios differ in some cases, but those minor differences may be neglected since the correlation between the ranking values is high. This result suggests that the pension fund portfolios are well diversified. By comparing the survived and the discontinued funds it becomes apparent that all discontinued funds performed worse than the survived funds. The Treynor ratios based on the WIG and the WIG20 are highly correlated, indicating robust results.

Table 2 about here 
All Sharpe ratios and a substantial number of Treynor ratios of Hungarian pension funds, presented in Table 3, are negative. All the negative Treynor ratios for Hungarian pension funds are due to negative total returns earned by these funds, rather than negative betas. All of the positive Treynor ratios are caused by negative total returns and negative betas of the corresponding funds. A negative $\beta$-factor results from a negative covariance between the excess return of the pension fund and the excess return of the market portfolio. This indicates a counter-cyclical investment strategy. It should be pointed out that the rankings of the Sharpe and Treynor ratios for most Hungarian pension fund differ substantially. This suggests that the majority of Hungarian pension fund portfolios are not well diversified. The considerable difference in Polish and Hungarian Sharpe and Treynor ratios indicates that Polish pension funds perform better than Hungarian ones, despite facing a relatively stricter regulatory framework. We consider possible explanations behind the relative underperformance of Hungarian pension funds later in this section.

Table 3 about here

The estimated performance measures for Polish pension funds based on the CAPM, are presented in Table 4 in Panel $(\mathrm{A})^{6}$. According to the single-index model, the funds outperform the market by $2.94 \%$ per annum using the capitalization-weighted market index based on the WIG20 and the MSCI-bond index. If the market index is based on the WIG and the MSCI-bond index, the results show no significant outperformance of Polish pension funds. As the WIG does account for dividends, while the WIG20 does not, the difference in the estimates is not only due to the included stocks.

The results for the Treynor-Mazuy and Henriksson-Merton model in Panel (A) suggest that Polish pension fund managers do not appear to possess any timing ability. However, when the market benchmark is based on the WIG20, both models indicate selectivity ability. Thus, pension fund managers show selectivity ability with respect to blue chip stocks and

\footnotetext{
${ }^{6}$ Transaction costs, operational costs and profit margins might influence the performance of pension funds. The cost structure is similar in Poland and Hungary in that operating fees are charged as a percentage of contributions to the pension fund and management fees are charged on the amount assets under management. It should be pointed out that the full extent of fees is often not transparent to the consumers in these countries (Impavido and Rocha (2006), Stanko (2003)). However, in the present paper we focus on the performance of pension funds in the countries, leaving the comparison of their overall economic efficiency for further research.
} 
show no such ability concerning stocks of smaller companies. These findings are in line with the fact that blue chips constitute a significant proportion of the funds' portfolios. Such portfolio structure is attributed to the existence of minimum required rate of return and the resulting security orientation of the managers (KNF (2007)).

The estimation results for the groups of survived and discontinued Polish pension funds in Panel (B) and (C) of Table 4 support our findings by the Sharpe and the Treynor ratio evidencing a worse performance of discontinued pension funds. While the estimated performance measures for survived pension funds are similar to those of the whole market, the performance measures of the discontinued funds are somewhat different. While discontinued funds also show positive alphas, their alphas are generally lower and statistically insignificant in comparison with those of the survived funds. In addition to the lacking selectivity ability, the results of both timing models deny the managers of discontinued funds any timing ability.

The empirical findings on the performance of Polish pension funds are therefore mixed. While we find evidence of selectivity ability when WIG20 is used as a benchmark for the equity market, the results do not hold when we use the broad-market index WIG as the benchmark. In the latter case, alphas decline in magnitude and cease to be statistically significant. This result is valid not only for the survived pension funds, but also for all pension funds. Thus this finding is not affected by the survivorship bias. A comparison of the survived and discontinued funds shows differences in their performances as reflected in the lower alphas for discontinued pension funds.

Our estimation results for the Polish pension fund market differ somewhat from those of Stanko (2003). The author finds statistically significant alphas for several unconditional models that range between 3 and $4.3 \%$ per annum. As it was mentioned above, we only find statistically significant alphas when WIG20 is used as a benchmark for the equity market performance. We also do not find evidence for timing ability detected by Stanko (2003). The differences in the results can be to some extent explained the longer sample used in our study and by somewhat differing methodology as Stanko (2003) does not account for time-variability in beta coefficients.

Table 4 about here

Table 5 shows the estimation results for Hungarian pension funds. The estimated coefficients of the Jensen model demonstrate that Hungarian pension funds were not able to beat 
the market in the observed period. In fact, they underperform the market by $5 \%$ per annum. In case of the Jensen model the beta-coefficient is not significantly different from zero. Since the coefficients of the interaction-dummies 1998-2001 are significantly different from zero ${ }^{7}$, this result indicates that the fund returns are not correlated with the market in the baselineyear. The estimations of the timing models lead to a minor increase in the $\alpha$ estimates in absolute terms compared to the Jensen model, still indicating that Hungarian pension funds were not able to outperform the market. The estimation results for the TreynorMazuy model indicates that Hungarian pension fund managers possess timing-ability, as the $\gamma$-coefficient is significantly different from zero. However, the Henriksson-Merton model does not detect any timing-ability. As time-variation in the beta coefficients is captured by the time-related interaction-dummies, the time-varying beta cannot be due to timing activities of the managers.

Table 5 about here

A number of reasons may be cited to explain this evidence of underperformance by Hungarian pension funds. The relatively short sample period and the dynamics of the t-bill rate might lead to the negative and insignificant $\alpha$-estimates. Unfavorable monetary and fiscal conditions over the sample period exerted pressure on the government securities markets and caused the Hungarian t-bill rate to be higher than in other Central European countries $^{8}$. The use of government bond yields as a benchmark by the Hungarian performance regulation further clearly affects the portfolio composition, as it keeps managers from investing into assets other than bonds. Most importantly, Hungarian pension fund managers face an illiquid and rather small stock market, with only a handful of liquid securities. During the sample period the number of securities listed on Budapest Stock exchange fluctuated between 46 and 66. The number of securities in BUX, the blue chip index, ranged from 13 to 20 (Budapest Stock Exchange, http://www.bse.hu/). This significantly limits managers' diversification opportunities. Finally, the pension fund legislative framework itself has been subject to numerous changes, providing additional uncertainties for managers and participants (World Bank (2007)). Therefore, the small and illiquid stock market, the design of fund performance benchmark, the adverse macroeconomic developments and the unstable

\footnotetext{
${ }^{7}$ Results for interaction-dummy-coefficients are not reported, but available upon request.

${ }^{8}$ The macroeconomic situation in Hungary is discussed in IMF (2006) and AKK (2004).
} 
regulatory framework are all likely to have contributed to the under-performance of pension funds in Hungary.

It should be pointed out that the reported evidence on underperformance by pension funds is not unique in literature. Several studies of pension funds in developed markets find that they may slightly underperform market benchmarks. For example, Blake and Timmermann (2002) analyze the portfolio composition and performance of UK pension funds during 1986-1994 using the Jensen regression. As UK pension fund managers face no constraints in regard to their investment decisions they hold a larger fraction in equities and a smaller fractions in bonds than pension funds in Poland and Hungary. Blake et al. (2002) present a cross-sectional distribution of unconditional $\alpha$-estimates, which ranges from $-4.59 \%$ per annum to $4.68 \%$ per annum. Thus, less than $50 \%$ of the observed UK pension funds achieve a positive $\alpha$. On average, UK pension funds have an $\alpha$ estimate of $-0.047 \%$ per annum. This indicates that UK pension funds tend to underperform the market in general. Our findings on Polish pension funds also show that a large amount of net assets does not necessarily guarantee the highest performance, being in line with the results of Blake et al. (2002) and Lakonishok et al. (1992) for the UK and the US market, respectively.

Christopherson et al. (1998) studied the performance of the US pension funds, which, like the UK pension funds, are also subject to the "prudent-man rule". The study is based on 185 US pension fund managers over the period between 1979 and 1990. In addition to the basic CAPM with one explanatory variable, they also estimate time-varying conditional alphas and betas of Ferson and Schadt (1996). They find that pension funds pursuing valueoriented strategy show negative alphas of $-3.30 \%$ when CRSP index is used as a benchmark. Growth-oriented pension funds show negative alphas of $-1.00 \%$ in case Russel style index is used as a benchmark. Growth- and value-oriented fund groups each account for about $22 \%$ of their sample. The above-mentioned empirical results show that underperformance is found among pension funds in the UK and US. The extent of underperformance, however, is lower than in case of Hungarian pension funds. These findings call for further, more detailed enquiries into the effects that various types of regulations have on pension fund performance and into the optimal design of the financial regulation systems. 


\section{Concluding Remarks}

The aim of this paper is to investigate the performance of mandatory defined-contribution pension funds on strictly regulated markets of Poland and Hungary and to provide a comparison of pension funds' performance between these two countries. For our comparative analysis we apply established performance measures. We find strong evidence of underperformance by Hungarian pension funds. Investment limits and performance regulations seem to influence the investment decisions of pension funds in both countries. In Poland they lead to similar portfolio composition decisions among the managers, while in Hungary they lead to an excess investment into government securities. Additionally, the very low liquidity and small size of the Hungarian equity market, along with unfavorable macroeconomic developments which affected government bond yields, the design of the fund performance benchmark and the instability of the regulatory framework in Hungary are possible reasons behind the weak performance of Hungarian pension funds. Thus, the success of the pension reform seems to depend, among other factors on the level of development of the domestic capital market. 


\section{References}

AKK (2004). Debt management report 2004 and earlier years. http://www.akk.hu.

Antolin, P., S. Blome, D. Karim, S. Payet, G. Scheuenstuhl, and J. Yermo (2009). Investment regulations and defined contribution pensions. OECD Working Papers on Insurance and Private Pensions No. $3 \%$.

AP Information Services (2009). International pension funds and their advisors 2008/2009.

Blake, D. and A. Timmermann (2002). Performance benchmarks for institutional investors: Measuring, monitoring and modifying investment behaviour. In J. Knight and S. Satchell (Eds.), Performance Measurement in Finance: Firms, Funds and Managers. Oxford.

Budapest Stock Exchange (2006). Annual report 2005 and earlier years. hppt://www.bse.hu.

Cesari, R. and F. Panetta (2002). The performance of Italian equity funds. Journal of Banking \& Finance 26, 99-126.

Chan-Lau, J. A. (2005). Pension funds and emerging markets. Financial Markets, Institutions and Instruments 14(3), 107-134.

Chevalier, J. and G. Ellison (1999). Are some mutual fund managers better than others? Cross-sectional patterns in behaviour and performance. The Journal of Finance 54, 875899.

Christopherson, J. A., W. E. Ferson, and D. A. Glassman (1998). Conditioning manager alphas on economic performance: Another look at the persistence of performance. The Review of Financial Studies 11, 111-142.

Driscoll, J. C. and A. C. Kraay (1998). Consistent covariance matrix estimation with spatially dependent panel sata. Review of Economics and Statistics 80, 549-560.

Fama, E. F. and K. R. French (1993). Common risk factors in the returns on stocks and bonds. Journal of Financial Economics 33, 3-56.

Ferson, W. and R. Schadt (1996). Measuring fund strategy and performance in changing economic conditions. The Journal of Finance 51, 425-462. 
Grinblatt, M. and S. Titman (1994). A study of monthly mutual funds returns and performance evaluation techniques. Journal of Financial and Quantitative Analysis 29, 419-444.

Henriksson, R. and R. Merton (1981). On market timing and investment performance. part ii. statistical procedures for evaluating forecasting skills. Journal of Business 54, 513-533.

HFSA (2005). Annual report 2005 and earlier years. http://www.pszaf.hu.

IMF (2006). Hungary: 2006 article iv consultation - staff report; staff supplement and public information notice on the executive board discussion. IMF Country Report 06/379.

Impavido, G. and R. Rocha (2006). Competition and performance in the Hungarian second pillar. World Bank Policy Research Working Paper 3876.

Jensen, M. C. (1968). The performance of mutual funds in the period 1945-1964. The Journal of Finance 23, 389-416.

KNF (2007). Open pension funds market in 2006. hppt://www.knf.gov.pl.

KNF (2008). Konkurencja na rynku ofe. http://www.knf.gov.pl.

Lakonishok, J., A. Shleifer, and R. Vishny (1992). The impact of institutional trading on stock prices. Journal of Financial Economics 32, 23-43.

Lehmann, B. and D. Modest (1987). Mutual fund performance: A comparison of benchmarks and benchmark comparisons. The Journal of Finance 42, 233-265.

OECD (2006). Survey of invstment regulations of pension funds 2006 and earlier years. www.oecd.org.

Prather, L. and K. Middleton (2006). Timing and selectivity of mutual fund managers. An empirical test of the behavioural decision making theory. Journal of Empirical Finance 13, 249-273.

Sharpe, W. F. (1966). Mutual fund performance. Journal of Business 39, 119-138.

Stanko, D. (2003). Polish pension funds, does the system work? Cost, efficiency and performance measurement issues. Working Paper.

Treynor, J. L. (1965). How to rate management of investment funds. Harvard Business Review 43, 63-75. 
Treynor, J. L. and K. Mazuy (1966). Can mutual funds outguess the market? Harvard Business Review 44, 131-136.

Voronkova, S. and M. Bohl (2005). Insitutional traders' behaviour in an emerging stock market: Empirical evidence on Polish pension fund investors. Journal of Business Finance and Accounting 32, 1537-1560.

World Bank (2007). Pension reform and the development of pension systems: An evaluation of world bank assistance. IEG Working Paper 39145.

Zalewska, A. (2006). Is locking domestic funds into the local market beneficial? Evidence from the Polish pension reforms. Emerging Markets Review 7(4), 339-360. 
Table 1: Portfolio Limits on Pension Fund Investment in Selected Asset Categories

\begin{tabular}{|c|c|c|c|c|}
\hline \multirow[b]{2}{*}{ Asset category } & \multicolumn{2}{|c|}{ Poland } & \multicolumn{2}{|c|}{ Hungary } \\
\hline & $\begin{array}{l}\text { Investment } \\
\text { limits }\end{array}$ & $\begin{array}{l}\text { Actual port- } \\
\text { folio share }\end{array}$ & $\begin{array}{l}\text { Investment } \\
\text { limits }\end{array}$ & $\begin{array}{l}\text { Actual port- } \\
\text { folio share }\end{array}$ \\
\hline Equity & 40.00 & 31.57 & 50.00 & 9.68 \\
\hline Real Estate & 0.00 & 0.00 & $\begin{array}{l}5.00 \text { directly, } \\
10.00 \text { together } \\
\text { with real estate } \\
\text { investment } \\
\text { funds }\end{array}$ & 0.00 \\
\hline Government bonds & No Limit & 63.79 & No Limit & 75.20 \\
\hline Investment Funds & 25.00 & 0.32 & 50.00 & 6.43 \\
\hline Loans & $\begin{array}{l}\text { Equal to the } \\
\text { investment in } \\
\text { the shares of } \\
\text { the borrower }\end{array}$ & 0.13 & 0.00 & 0.00 \\
\hline Bank Deposits & 20.00 & 3.03 & No Limit & 0.00 \\
\hline Foreign Assets & 5.00 & 0.57 & 30.00 & N.A. \\
\hline
\end{tabular}

Note: The table shows the quantitative investment limits and actual shares of assets in the portfolio for Polish and Hungarian pension funds, indicated as \% of the pension funds' investment portfolios. The quantitative investment restrictions refer to 2006 for Polish mandatory (open) pension funds and to 2004 for Hungarian mandatory pension funds (OECD (2006)). The actual shares of assets in the portfolios of Polish pension funds are calculated using data provided by www.knf.gov.pl. The shares of assets in Hungarian pension funds portfolios are calculated using the arithmetic average for all pension funds for the period of 1998 to 2004 given in the dataset provided by the PSZAF. Data on investments in foreign assets by Hungarian pension funds is not available. 
Table 2: Sharpe- and Treynor-Ratios of Polish Pension Funds

\begin{tabular}{|c|c|c|c|c|c|c|c|}
\hline & \multirow[b]{2}{*}{ Market Share } & \multicolumn{2}{|c|}{ Sharpe Ratio } & \multicolumn{4}{|c|}{ Treynor Ratio } \\
\hline & & Value & Rank & WIG20 & Rank & WIG & Rank \\
\hline \multicolumn{8}{|c|}{ (A) Survived Pension Funds } \\
\hline Commercial Union & $26.65 \%$ & 0.1628 & 6 & 0.0589 & 7 & 0.0531 & 7 \\
\hline ING NNP & $23.44 \%$ & 0.1675 & 5 & 0.0599 & 6 & 0.0549 & 4 \\
\hline PZU & $13.73 \%$ & 0.1709 & 3 & 0.0621 & 3 & 0.0543 & 5 \\
\hline AIG & $8.29 \%$ & 0.1425 & 12 & 0.0502 & 12 & 0.0457 & 12 \\
\hline AXA & $4.30 \%$ & 0.1580 & 10 & 0.0574 & 8 & 0.0524 & 8 \\
\hline Generali & $3.68 \%$ & 0.1684 & 4 & 0.0609 & 5 & 0.0539 & 6 \\
\hline Nordea & $3.52 \%$ & 0.1750 & 2 & 0.0618 & 4 & 0.0555 & 3 \\
\hline Bankowy & $3.09 \%$ & 0.1027 & 15 & 0.0413 & 15 & 0.0380 & 15 \\
\hline Skarbiec Emerytura & $2.52 \%$ & 0.1272 & 13 & 0.0435 & 14 & 0.0417 & 14 \\
\hline Allianz Polska & $2.46 \%$ & 0.1531 & 11 & 0.0550 & 11 & 0.0512 & 9 \\
\hline AEGON & $2.19 \%$ & 0.1592 & 7 & 0.0563 & 9 & 0.0510 & 10 \\
\hline Pocztylion & $2.02 \%$ & 0.1250 & 14 & 0.0461 & 13 & 0.0418 & 13 \\
\hline Pekao & $1.62 \%$ & 0.1582 & 9 & 0.0561 & 10 & 0.0510 & 11 \\
\hline DOM & $1.53 \%$ & 0.1592 & 8 & 0.0677 & 2 & 0.0582 & 2 \\
\hline Polsat & $0.96 \%$ & 0.2278 & 1 & 0.0846 & 1 & 0.0758 & 1 \\
\hline Average & & 0.1572 & & 0.0575 & & 0.0519 & \\
\hline
\end{tabular}

(B) Discontinued Pension Funds

\begin{tabular}{lrrrrrr}
\hline Arka Invesco & -0.2884 & 20 & -0.1255 & 20 & -0.1192 & 20 \\
Epoka & -0.4007 & 21 & -0.2343 & 21 & -0.2240 & 21 \\
Kredyt Banku & -0.0306 & 18 & -0.0114 & 18 & -0.0104 & 18 \\
Rodzina & 0.0363 & 16 & 0.0270 & 16 & 0.0214 & 16 \\
ego & -0.0207 & 17 & -0.0073 & 17 & -0.0069 & 17 \\
Pioneer & -0.0523 & 19 & -0.0502 & 19 & -0.0402 & 19 \\
\hline Average & -0.1261 & & -0.0670 & & -0.0632 \\
(C) All Pension Funds & & & & & & \\
\hline Average & 0.0762 & & 0.0219 & & 0.0190 \\
\hline \hline
\end{tabular}

Note: The longest sample period is June 301999 until August 31 2007. Survivors are sorted according to their market share in August 31 2007. For the calculation of the Treynor Ratios the capitalization-weighted market indices (based on the WIG20 and the WIG, respectively, and on the MSCI bond index) are used as market portfolios. 
Table 3: Sharpe- and Treynor-Ratios of Hungarian Pension Funds

\begin{tabular}{|c|c|c|c|c|}
\hline & \multicolumn{2}{|c|}{ Sharpe Ratio } & \multicolumn{2}{|c|}{ Treynor Ratio } \\
\hline & Value & Rank & BUX & Rank \\
\hline \multicolumn{5}{|c|}{ All pension funds } \\
\hline 1 & -0.3349 & 1 & 0.2116 & 9 \\
\hline 2 & -0.9032 & 12 & -0.7009 & 14 \\
\hline 3 & -2.4869 & 18 & 2.5344 & 4 \\
\hline 4 & -0.6509 & 6 & 0.3723 & 8 \\
\hline 5 & -0.7673 & 9 & -0.5778 & 13 \\
\hline 6 & -0.7737 & 10 & -0.3244 & 11 \\
\hline 7 & -0.5448 & 4 & 0.5362 & 7 \\
\hline 8 & -1.1744 & 13 & 0.6645 & 5 \\
\hline 9 & -0.6757 & 7 & 0.5609 & 6 \\
\hline 10 & -1.5921 & 15 & -1.0578 & 15 \\
\hline 11 & -0.8883 & 11 & -7.6379 & 18 \\
\hline 12 & -0.5967 & 5 & 2.9225 & 2 \\
\hline 13 & -0.3686 & 3 & 2.8171 & 3 \\
\hline 14 & -0.3400 & 2 & 0.1316 & 10 \\
\hline 15 & -1.2894 & 14 & -2.7746 & 17 \\
\hline 16 & -1.5941 & 16 & 2.9549 & 1 \\
\hline 17 & -0.7616 & 8 & -0.4355 & 12 \\
\hline 18 & -1.9346 & 17 & -2.2627 & 16 \\
\hline Average & -0.9821 & & -0.1147 & \\
\hline
\end{tabular}

Note: The longest sample period is $1998 \mathrm{q} 1$ until 2004q4. All pension funds are considered. For the calculation of the Treynor ratio the capitalization-weighted market index (based on BUX and MSCI-bond index) is used as market portfolio. 
Table 4: Pooled Estimates for the CAPM-Based Models for Polish Pension Funds

\begin{tabular}{|c|c|c|c|c|}
\hline & & $\alpha$ & $\beta$ & $\gamma$ \\
\hline \multicolumn{5}{|c|}{ (A) All Pension Funds } \\
\hline WIG20 & $\begin{array}{l}\text { Jensen } \\
\text { Treynor-Mazuy } \\
\text { Henriksson-Merton }\end{array}$ & $\begin{array}{l}0.0294^{* * *} \\
0.0326^{* * *} \\
0.0346^{* * *}\end{array}$ & $\begin{array}{l}0.9975^{* * *} \\
0.9963^{* * *} \\
0.9780^{* * *}\end{array}$ & $\begin{array}{l}-0.0267 \\
-0.0383\end{array}$ \\
\hline WIG & $\begin{array}{l}\text { Jensen } \\
\text { Treynor-Mazuy } \\
\text { Henriksson-Merton }\end{array}$ & $\begin{array}{l}0.0120 \\
0.0088 \\
0.0156\end{array}$ & $\begin{array}{l}0.9856^{* * *} \\
0.9832^{* * *} \\
0.9735^{* * *}\end{array}$ & $\begin{array}{r}0.0300 \\
-0.0308\end{array}$ \\
\hline \multicolumn{5}{|c|}{ (B) Survived Pension Funds } \\
\hline WIG20 & $\begin{array}{l}\text { Jensen } \\
\text { Treynor-Mazuy } \\
\text { Henriksson-Merton }\end{array}$ & $\begin{array}{l}0.0318^{* * *} \\
0.0330^{* * *} \\
0.0338^{* * *}\end{array}$ & $\begin{array}{l}0.9950^{* * *} \\
0.9946^{* * *} \\
0.9877^{* * *}\end{array}$ & $\begin{array}{l}-0.0104 \\
-0.0144\end{array}$ \\
\hline WIG & $\begin{array}{l}\text { Jensen } \\
\text { Treynor-Mazuy } \\
\text { Henriksson-Merton }\end{array}$ & $\begin{array}{l}0.0130 \\
0.0096 \\
0.0123\end{array}$ & $\begin{array}{l}0.9783^{* * *} \\
0.9724^{* * *} \\
0.9807^{* * *}\end{array}$ & $\begin{array}{l}0.0380 \\
0.0054\end{array}$ \\
\hline \multicolumn{5}{|c|}{ (C) Discontinued Pension Funds } \\
\hline WIG20 & $\begin{array}{l}\text { Jensen } \\
\text { Treynor-Mazuy } \\
\text { Henriksson-Merton }\end{array}$ & $\begin{array}{l}0.0075 \\
0.0234 \\
0.035\end{array}$ & $\begin{array}{l}0.7829^{* * *} \\
0.8035^{* * *} \\
0.6928^{* * *}\end{array}$ & $\begin{array}{l}-0.1241 \\
-0.1983\end{array}$ \\
\hline WIG & $\begin{array}{l}\text { Jensen } \\
\text { Treynor-Mazuy } \\
\text { Henriksson-Merton }\end{array}$ & $\begin{array}{l}0.0022 \\
0.0131 \\
0.0278\end{array}$ & $\begin{array}{l}0.8928^{* * *} \\
0.9135^{* * *} \\
0.7972^{* * *}\end{array}$ & $\begin{array}{l} \\
-0.1139 \\
-0.2241\end{array}$ \\
\hline
\end{tabular}

Note: The table presents the pooled OLS estimates of the CAPM regressions. The market factor used is capitalization-weighted and based on the WIG20 and the WIG as equity-market benchmarks and the MSCI-bond index as a benchmark for government bonds. The models are augmented by interaction dummies capturing timevariability in beta coefficients. All models are estimated with Driscoll-Kraay standard errors. The partitioning into groups is the following: In (A) all funds are included, in (B) only survived funds including late-starters are considered and in (C) only funds that started their activity later than June 1999 and quit the market prior to July 2005 are considered. $* * * * * *$ represent estimates significant at $10 \%, 5 \%$, and $1 \%$, respectively. The estimated dummycoefficients are not reported, but available upon request. 
Table 5: Pooled Estimates for the CAPM-Based Models for Hungarian Pension Funds

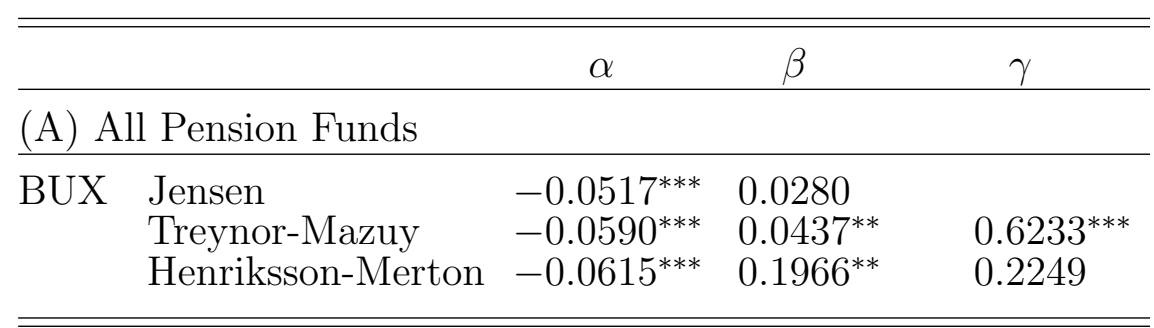

Note: The table presents the pooled estimation results of the CAPM-models for the Hungarian pension funds. The market factor used is a capitalization-weighted combination of bond and equity benchmarks. BUX index is used as the benchmark for equity market, while the local MSCI-bond index is used as a benchmark for the bond market. The models are augmented by interaction dummies capturing time-variability in beta coefficients. All models are estimated with Driscoll-Kraay standard errors. ${ }^{*}, * * * * *$ represent estimates significant at $10 \%, 5 \%$, and $1 \%$, respectively. The estimated dummy-coefficients are not reported, but available upon request. 